\title{
Rancang Bangun Aplikasi Manajemen Event Berbasis Sms Gateway Pada BKKBN Kabupaten Madiun
}

\author{
Emis Safitri Purwaningsih \\ Universitas PGRI Madiun \\ Email: emissafitri94@gmail.com
}

\begin{abstract}
ABSTRAK
BKKBN adalah salah satu instansi pelayanan pada bidang KB. Selama ini untuk promosi dilakukan dengan penyebaran poster dan dilakukan kunjungan ke setiap rumah dengan waktu tertentu. Namun, hal ini dirasa kurang efektif dan menyebabkan jumlah karyawan yang diperbantukan ke kecamatan menjadi lebih banyak. Oleh karena itu penulis merancang dan membangun Aplikasi Manajemen Event Berbasis SMS Gateway pada BKKBN Kabupaten Madiun. Penelitian ini bertujuan untuk mengetahui perancangan dan kelayakan Aplikasi Manajemen Event Berbasis SMS Gateway pada BKKBN Kabupaten Madiun. Penelitian dilakukan di BKKBN Kabupaten Madiun dengan jumlah karyawan yang bekerja di kantor berjumlah 20 karyawan. Metode penelitian yang digunakan adalah metode waterfall. Penelitian dilakukan dengan tahapan analisis kebutuhan, desain sistem, penulisan kode program, pengujian program dan penerapan program.Teknik analisa data yang digunakan untuk menguji kelayakan Aplikasi Manajemen Event Berbasis SMS Gateway dengan menggunakan lembar validitas, lembar angket respon dan lembar observasi. Prosentase yang dihasilkan pada lembar validitas $91 \%$ (sangat valid) dari koresponden sebanyak 4 ahli. Prosentase yang dihasilkan pada angket respon 96\% (sangat praktis) dari koresponden sebanyak 12 staff. Kenaikan prosentase pada hasil observasi sebesar 63,33\% yang artinya dengan adanya aplikasi maka efektivitas pekerjaan semakin tinggi. Dari ketiga teknik analisa tersebut disimpulkan bahwa Aplikasi Manajemen Event Berbasis SMS Gateway pada BKKBN Kabupaten Madiun layak digunakan.
\end{abstract}

\section{Kata Kunci: Aplikasi, Manajemen Event, SMS Gateway}

\section{PENDAHULUAN}

Saat ini perkembangan teknologi sudah semakin pesat seiring dengan semakin banyaknya permintaan masyarakat akan teknologi tersebut. Perkembangan teknologi berkembang secara drastis dan terus berevolusi. Salah satu perkembangan teknologi yang banyak menjadi sorotan adalah perkembangan Software Aplikasi. Tidak hanya di kalangan swasta, kalangan dinas pun banyak yang menggunakan Software Aplikasi. Pada beberapa dinas yang fokus pada pelayanan publik, Software Aplikasi sangat berguna untuk memberi pelayanan yang lebih cepat dan efektif.

BKKBN (Badan Koordinasi

Keluarga Berencana Nasional) Kabupaten Madiun merupakan salah satu dinas yang berfokus pada pelayanan publik. Event yang sering dilaksanakan di BKKBN antara lain penyuluhan dan pelaksanaan
KB secara massal. Penyuluhan biasanya dilakukan dengan membagikan poster dan mendatangi setiap rumah dengan kurun waktu tertentu. Untuk pemberitahuan adanya KB secara massal dilakukan dengan memberitahukan pengumuman di kecamatan. Dengan cara seperti ini ditakutkan penyuluhan serta pemberitahuan adanya kegiatan KB tidak diterima secara menyeluruh oleh masyarakat. Untuk masyarakat yang mau bertanya tentang $\mathrm{KB}$ juga harus ke kacamatan atau langsung ke kantor BKKBN. Hal ini akan membuat masyarakat enggan untuk bertanya dikarenakan harus pergi ke tempat tersebut.

Berdasarkan permasalahan tersebut BKKBN perlu dibuat adanya aplikasi manajemen event berbasis sms gateway yang saling terintegrasi untuk lebih mempermudah sistem kerja 
sehingga dapat membantu pengguna untuk bekerja lebih optimal dan efisien. Dengan menggunakan aplikasi ini diharapkan proses promosi menjadi lebih efektif dan mudah, tanya jawab terhadap masyarakat bisa dilakukan dimana saja dan kapan saja, serta pencatatan datadata terkait sms masuk dan keluar dapat disimpan dengan suatu aplikasi yang saling terintergrasi sehingga nantinya memudahkan dalam proses pencarian suatu data sms. Oleh karena itu, penulis merancang dan membangun Aplikasi Manajemen Event Berbasis SMS Gateway pada BKKBN Kabupaten Madiun.

\section{KAJIAN TEORI}

Menurut Cahyaningtyas dan Iriyani (2015:16), perancangan adalah suatu proses pemilihan dan pemikiran yang menghubungkan fakta-fakta berdasarkan asumsi-asumsi yang berkaitan dengan masa datang dengan menggambarkan dan merumuskan kegiatan-kegiatan tertentu untuk mencapai tujuan-tujuan serta memberikan penjelasan bagaimana cara pencapaiannya.

Menurut Utami dan Tesnawati (2015: 2), aplikasi merupakan program yang berisikan perintah-perintah untuk melakukan pengolahan data.

Menurut Noor (dalam Dewi dan Runyke, 2013: 85), proses perencanaan event dimulai menentukan tujuan yang dapat diterima dengan jelas oleh setiap anggota tim yang akan terlibat dalam pelaksanaan event.

Menurut Aryani, dkk (2015: 179180), SMS Gateway memungkinkan untuk sebuah pesan dapat di kirimkan dari sebuah aplikasi melalui jaringan operator telekomunikasi untuk di kirimkan ke nomor nomor tujuan. Dengan digunakannya aplikasi SMS Gateway, sumber-sumber data bisa didapatkan langsung dari basis data untuk selanjutnya diolah menjadi informasi dan dikirimkan secara sistemik/tanpa manual kepada banyak nomor dalam satu waktu.

\section{METODE PENELITIAN}

Metode pengembangan sistem yang digunakan pada penelitian ini yaitu metode waterfall.

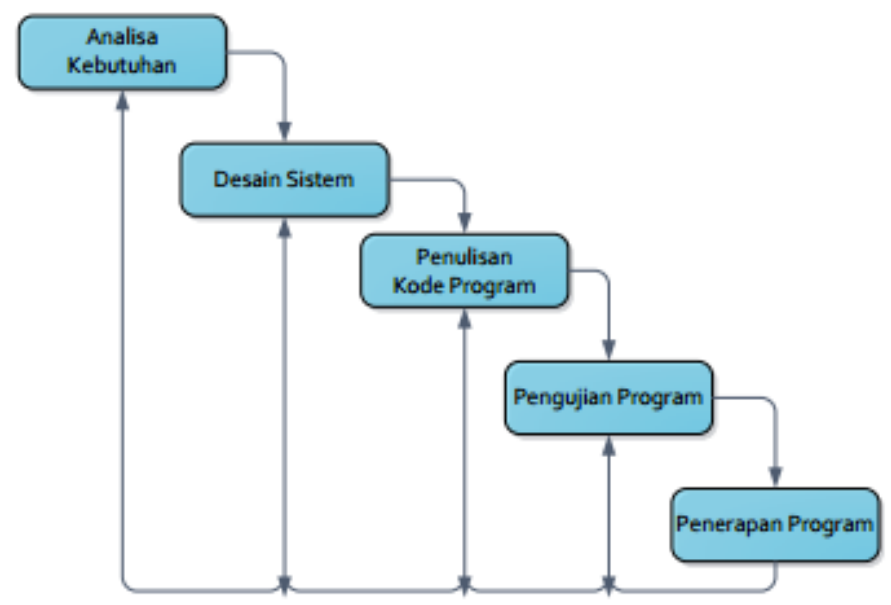

Gambar 1. Model Waterfall

\section{HASIL DAN PEMBAHASAN \\ Perancangan Sistem}

1. Diagram Konteks

Diagram konteks disini menjelaskan alur data pada sistem secara keseluruhan.

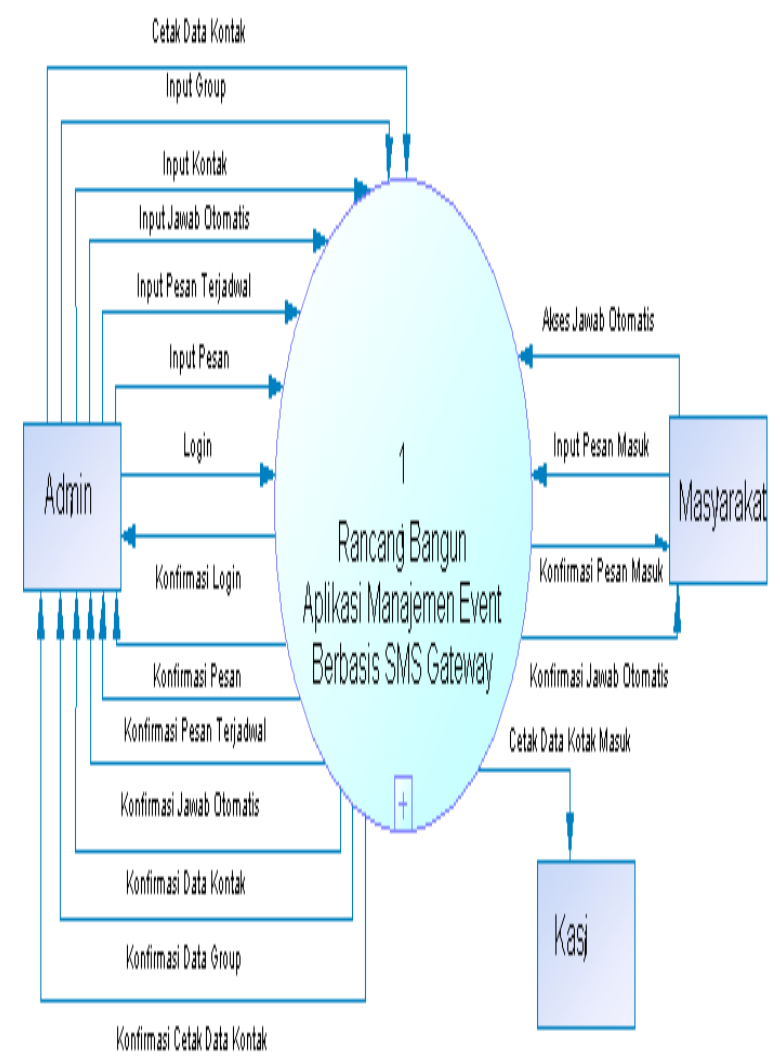

Gambar 2. Diagram Konteks 


\section{DFD (Data Flow Diagram)}

DFD atau Data Flow Diagram adalah sebuah diagram yang menggambarkan aliran sebuah data dalam suatu sistem.

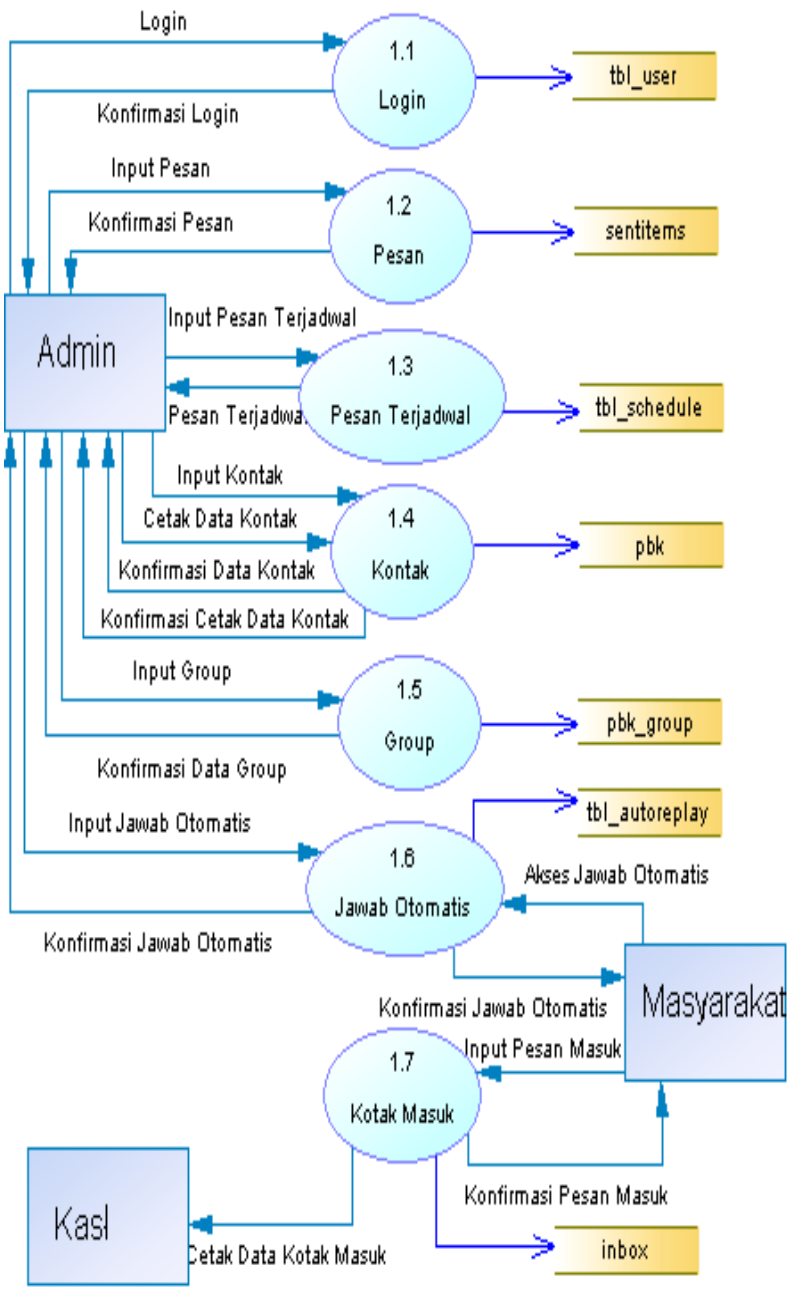

Gambar 3. DFD

\section{Tampilan Hasil}

1. Halaman Login

\section{LOGIN APLIKASI MANAJEMEN}

EVENT BERBASIS SMS GATEWAY

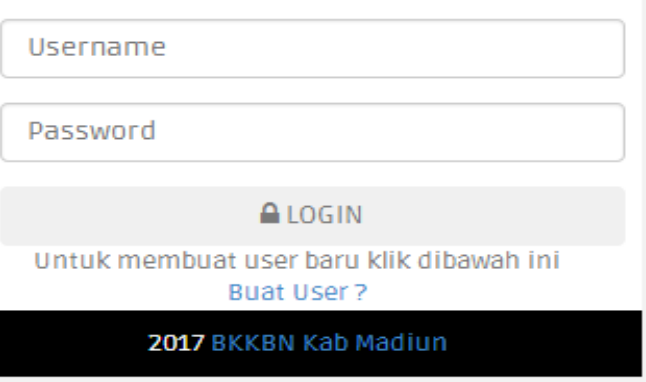

Gambar 4. Tampilan Halaman Login

\section{Tampilan Menu Utama}

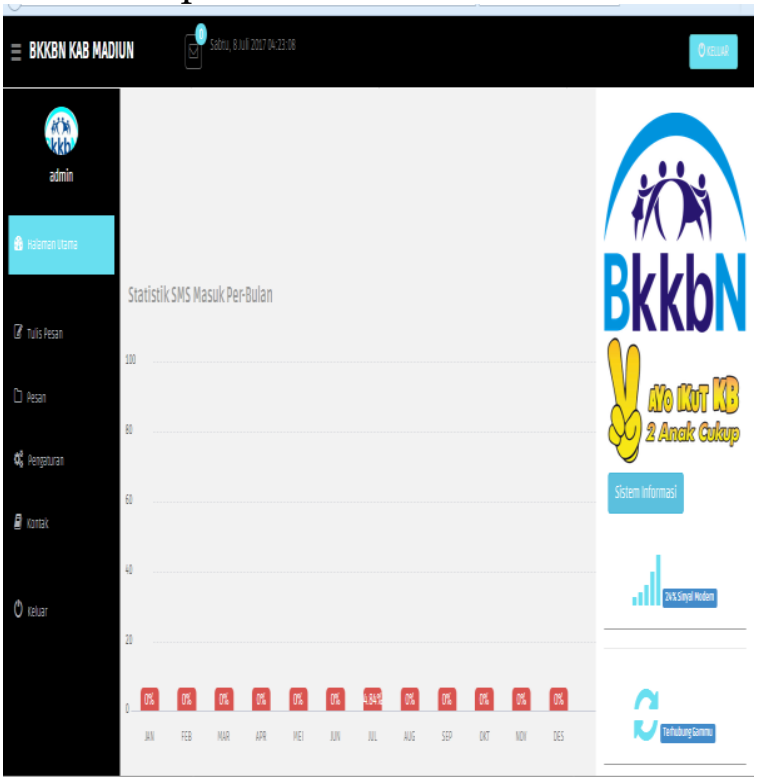

Gambar 5. Tampilan Menu Utama 3. Menu Tulis Pesan

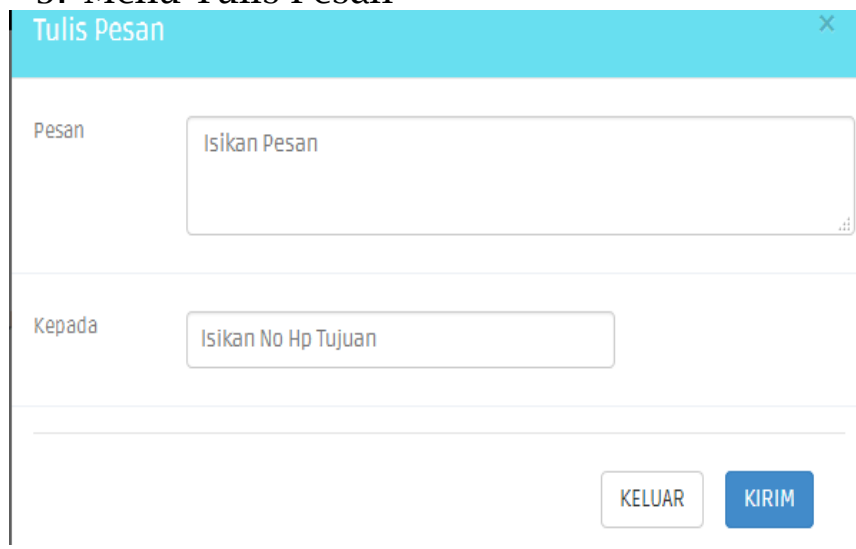

Gambar 6. Tampilan Menu Tulis Pesan

4. Menu Kotak Masuk ;otak Masuk
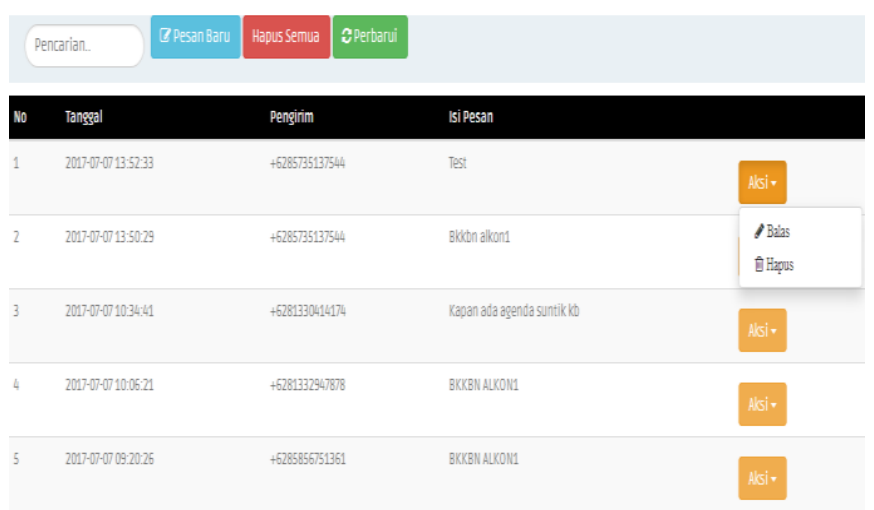

Gambar 7. Tampilan Menu Kotak Masuk 
5. Tampilan Cetak Kotak Masuk BKKBNKABUPATEN MADUN CETAK LAPORAN KOTAK MASUK

\begin{tabular}{|c|c|c|c|}
\hline 110 & TAMGGAL & PENGIRIM & PESAII \\
\hline 1. & $2017.07 \cdot 0713: 5233$ & - 28257356137844 & Test \\
\hline 2 & $2017 \cdot 07 \cdot 0713: 50: 29$ & $\$ 2857255137844$ & Bekbon aliont \\
\hline 3. & $2017.07 \cdot 0710: 34.41$ & $\$ 2821330414174$ & Kopan sods ggendos suttik kb \\
\hline 4 & $2017 \cdot 07 \cdot 071000821$ & $\$ 281332294878$ & BWENALKON1 \\
\hline 5 & $2017 \cdot 07 \cdot 070920.28$ & 42288687511381 & BWEN ALKON1 \\
\hline 8 & $2017 \cdot 07 \cdot 0709: 18: 13$ & $\$ 2858688751381$ & BWENALKON1 \\
\hline 7 & $2017.07 \cdot 0708: 40: 29$ & NDDSAT & 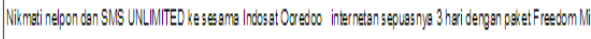 \\
\hline 8 & $2017 \cdot 07 \cdot 0708: 40: 27$ & MOBOINDOSAT & 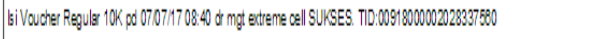 \\
\hline 9 & $2017 \cdot 07 \cdot 07084.45 .51$ & $\$ 2858008119943$ & 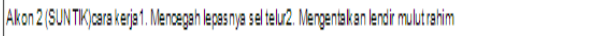 \\
\hline 10 & $2217 \cdot 07 \cdot 070830: 42$ & $\$ 2858688751281$ & BWGN ALKON2 \\
\hline 11 & $2017 \cdot 07 \cdot 07082421$ & 4225800119943 & 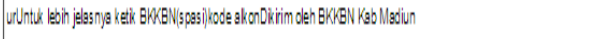 \\
\hline 12 & $2017 \cdot 07 \cdot 07082420$ & $\$ 2285808119943$ & 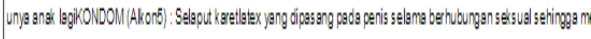 \\
\hline 13 & $2017 \cdot 07 \cdot 07082418$ & 4285808119943 & 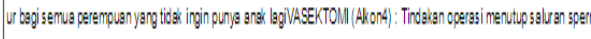 \\
\hline 14. & $2017 \cdot 07 \cdot 070824: 18$ & $\$ 2858008119943$ & minum setiap hriselama 28 his \\
\hline 15 & $2017 \cdot 07 \cdot 070824: 13$ & $\$ 285808119943$ & 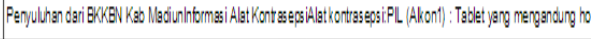 \\
\hline 18 & $2017.07 \cdot 080451: 20$ & +2285868751281 & BKMEN CE2 \\
\hline 17 & $2017 \cdot 07 \cdot 0515: 40.18$ & $\$ 2286868751381$ & BWEN Alont \\
\hline 18 & $2017 \cdot 07 \cdot 05080858: 13$ & 422868675151381 & BWMEN CE2 \\
\hline 19 & $2217.07 \cdot 05006 \cdot 49.37$ & +82858687513131 & BWKN SP1 \\
\hline
\end{tabular}

Gambar 8. Tampilan Cetak Kotak Masuk

\section{Menu Kotak Keluar}

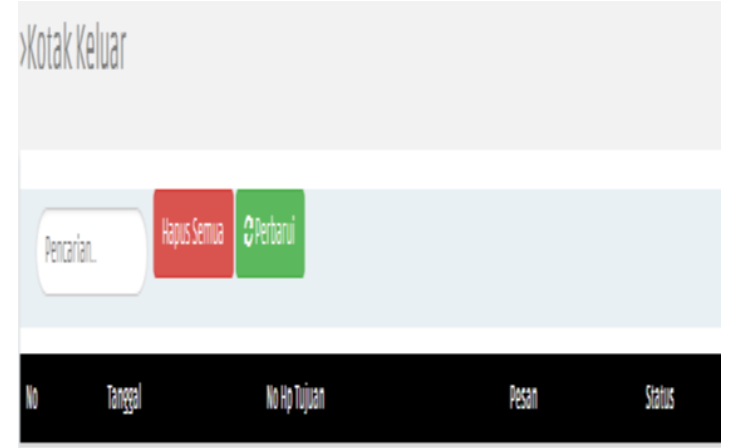

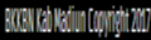

Gambar 9. Tampilan Menu Kotak Keluar

\section{Menu Pesan Terkirim} Jessan Telkirim

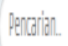

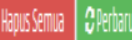

\section{Baryal Pareing pean}

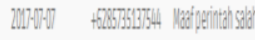

13242

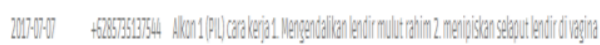

1391106

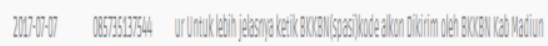

$13: 79$

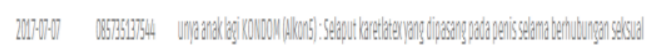

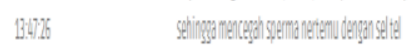

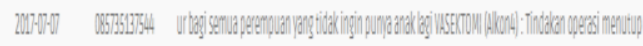

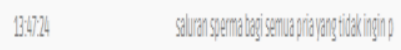

Gambar 10. Tampilan Menu Pesan Terkirim

8. Menu Pesan Group

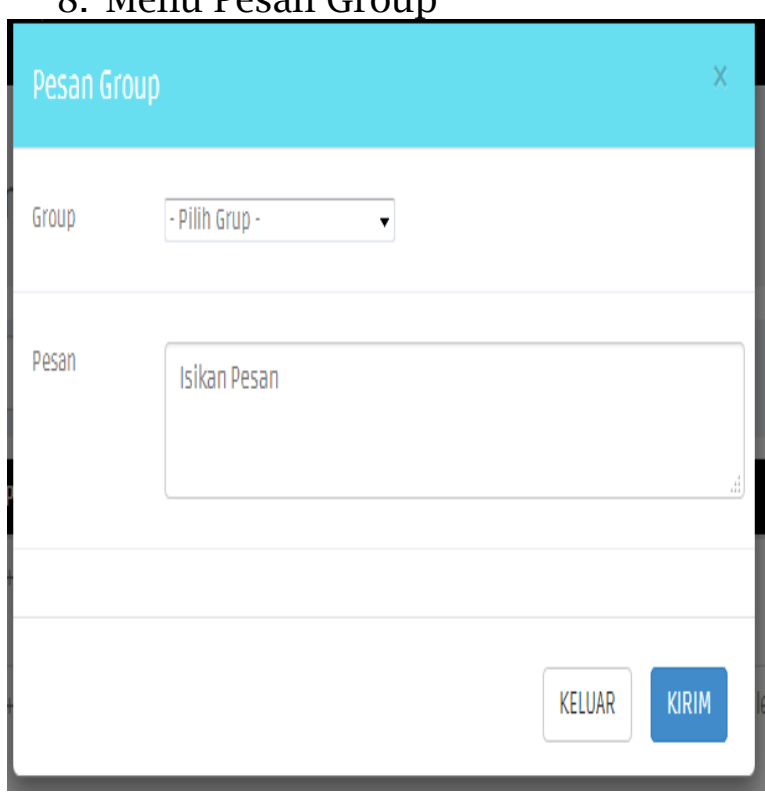

Gambar 11. Tampilan Menu Pesan Group 


\section{Menu Pesan Terjadwal}

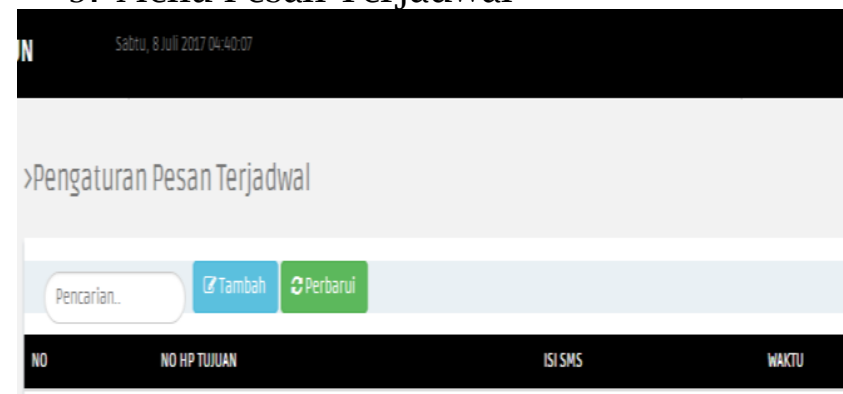

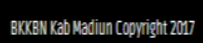

Gambar 12. Tampilan Menu Pesan Terjadwal 10. Form Input Pesan Terjadwal

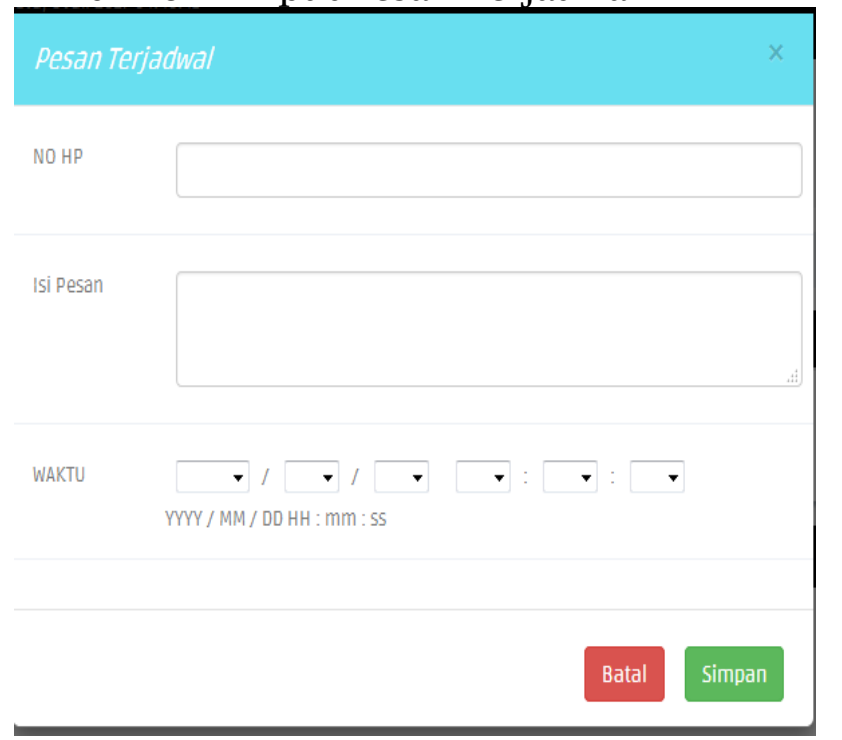

Gambar 13. Tampilan Form Input Pesan Terjadwal

11. Menu Jawab Otomatis

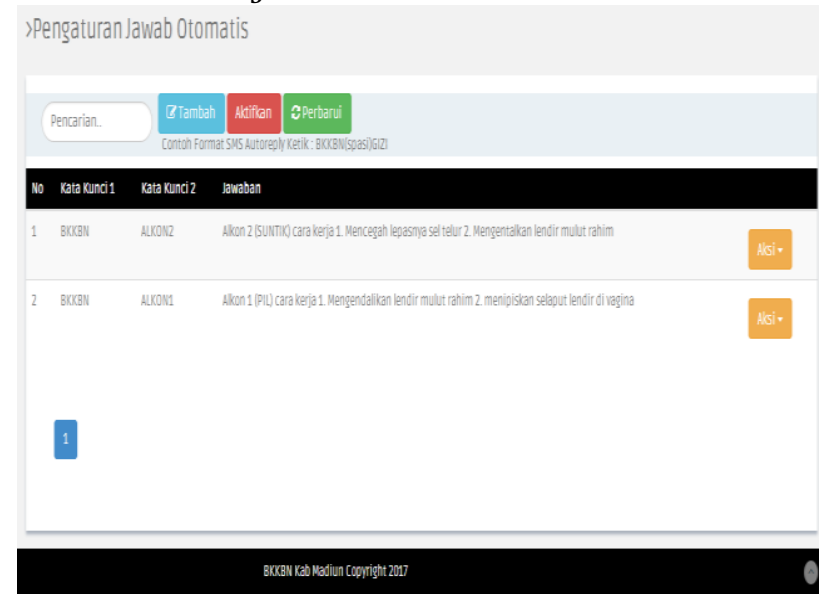

Gambar 14. Tampilan Menu Jawab Otomatis
12. Tampilan Form Input Jawab Otomatis

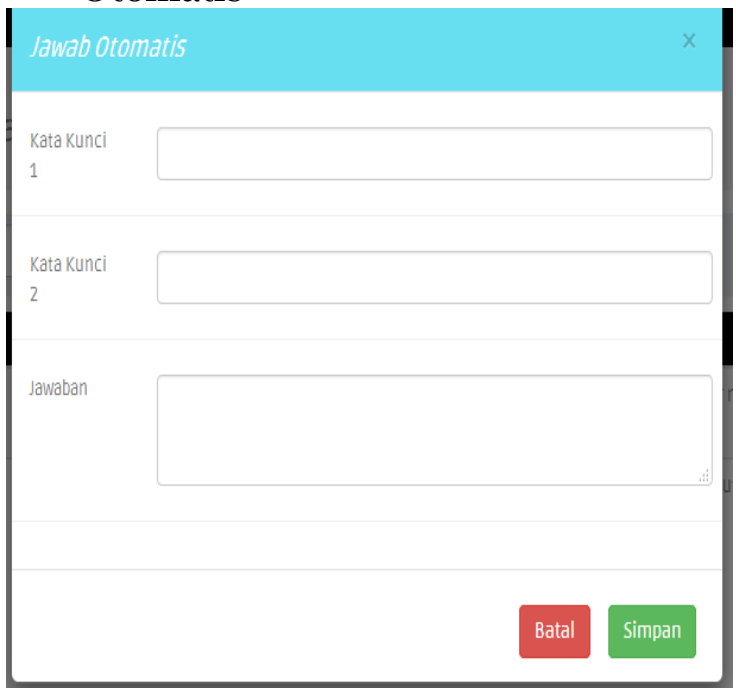

Gambar 15. Tampilan Form Input Jawab Otomatis

13. Menu Kontak sDaftar Kontak

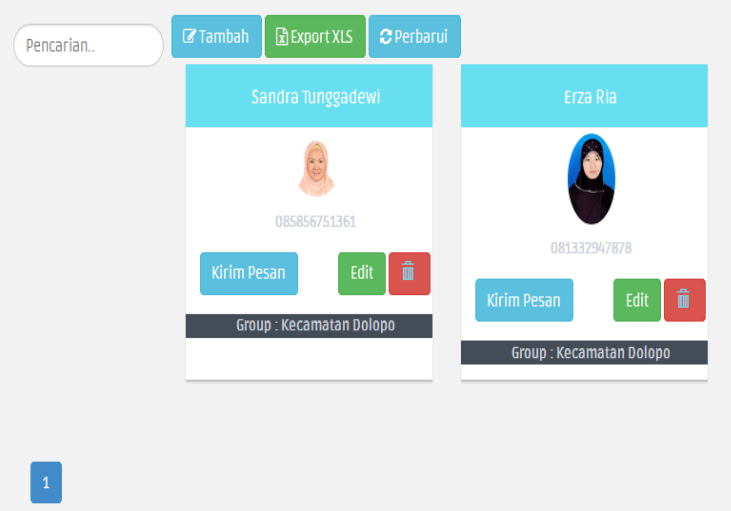

Gambar 16. Tampilan Menu Kontak 14. Cetak Data Kontak

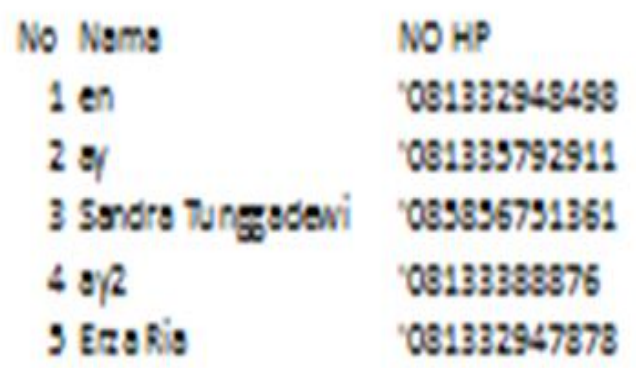

Gambar 17. Tampilan Cetak Data Kontak 


\section{Menu Daftar Kontak}

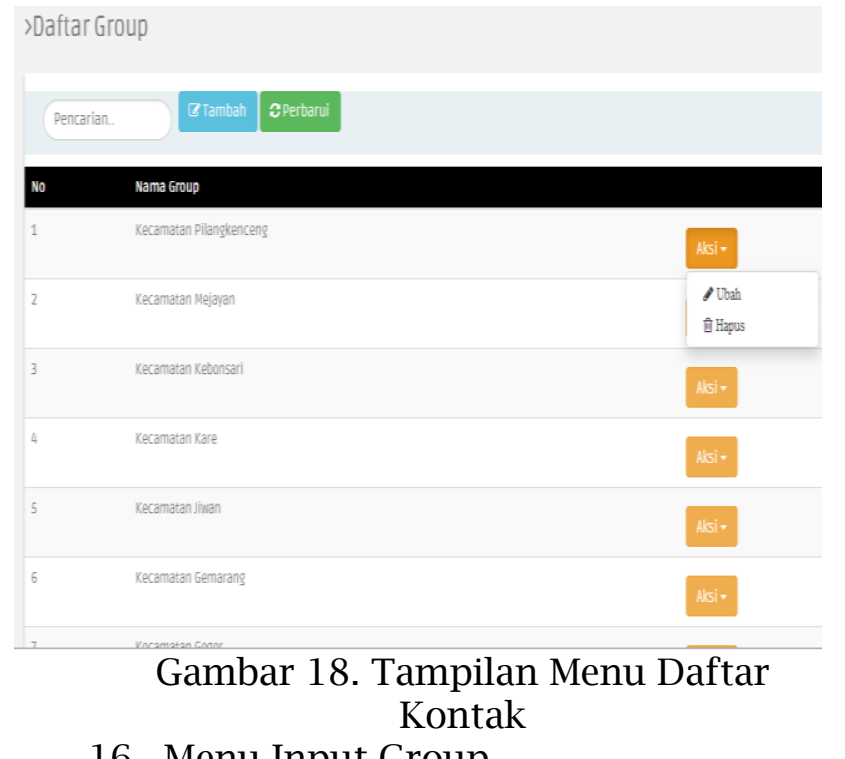

16. Menu Input Group

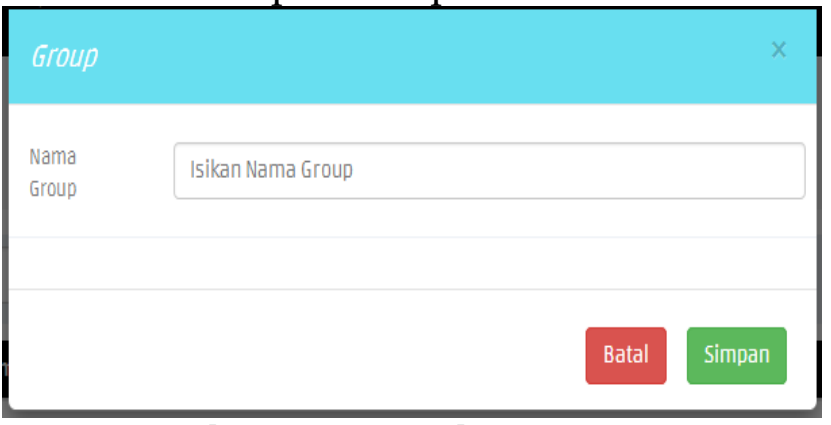

Gambar 19. Tampilan Menu Input Group

\section{KESIMPULAN}

Skripsi dengan judul "Rancang Bangun Aplikasi Manajemen Event Berbasis SMS Gateway pada BKKBN Kabupaten Madiun" mengangkat studi kasus pada BKKBN Kabupaten Madiun. Dari hasil penelitian yang didapat, diambil kesimpulan bahwa:

1. Aplikasi Manajemen Event Berbasis SMS Gateway ini layak digunakan pada BKKBN Kabupaten Madiun.

2. Aplikasi Manajemen Event Berbasis SMS Gateway ini efektif digunakan pada BKKBN Kabupaten Madiun

\section{Daftar Pustaka}

Cahyaningtyas, R. dan Iriyani, S. (2015). Perancangan Sistem Informasi Perpustakaan Pada SMP Negeri 3 Tulakan Kecamatan Tulakan Kabupaten Pacitan. Indonesian Journal on Networking and
Security(IJNS). Vol. 4 No. 2 ,ISSN: 2302-5700 (hlm.15-20).

Dewi, M. dan Runyke, M. (2013). Peran Public Relation dalam Manajemen Event (Studi Terhadap Peran Publlic Speaking Relations Galeria Mall dan Plaza Ambarrukmo dalam Pengelolaan Event Tahun 2013). Jurnal Komunikasi Vol. 8 No. 1 ,ISSN: 19907-989X (hlm.7990).

Utami, R.R. dan Tresnawati, D. (2015). Pengembangan Aplikasi Pengenalan Fiqih Darah Wanita dengan Menggunkan Sistem Multimedia. Jurnal STT Garut. Vol. 12 No. 1 ,ISSN: 2302-7339 (hlm.2-7) 